\title{
NEW LINGULOID SHELLS FROM LOWER ORDOVIGIAN AND MIDDLE PALAEOZOIC ROGKS OF NEW SOUTH WALES
}

By H. O. FLetcher

Australian Museum

Plates 31 and 32

Manuscript received, $\mathbf{1} 4^{-4}-6 \mathbf{I}$

\begin{abstract}
New species of linguloid shells, Ectenoglossa brunnschweileri, Obolus mootwingeensis and Lingulella (Leptembolon) gnaltaensis, are described and figured from Lower Ordovician (Tremadoc) rocks of the Gnalta Stage in the West Darling District of New South Wales. Recent palaeontological evidence of the age of the Mulga Downs Formation, East Darling District, previously correlated with the Mootwingee Series, is also mentioned. New species of Lingula are also described and figured from various Upper Silurian and Devonian localities.
\end{abstract}

\section{INTRODUCTION}

Rocks of the Mootwingee Series are exposed west of the Darling River in the Mootwingee Ranges and contiguous slopes. The term Mootwingee Series was introduced for this group of rocks by Andrews (1922, p. 7 I) and although recognizing in general appearance a similarity to beds of Devonian age in the eastern portions of the State he was of the opinion they were much older than Devonian and were at least of very early Palaeozoic age.

The Mootwingee Series was subdivided into a lower or Gnalta Stage and an upper or Mootwingee Stage by Kenny (1934, p. 53), who stated that there was no evidence of the specific age of the Mootwingee Series beyond the fact they are postTorrowangee and pre-Jurassic. It was pointed out by Kenny (1934, p. 53) and by Mulholland (I940, p. I6) that the rocks of the Mulga Downs Formation, which occur east of the Darling River, were lithologically and structurally very similar to those of the Mootwingee Stage. Fossil remains had not been found in either of the sequences but it was accepted by many that they were contemporaneous and were of Upper Devonian age.

The first fossils found in rocks of the Mootwingee Series were a series of linguloid shells which were collected by R. C. Sprigg, Geosurveys of Australia Pty. Ltd., from the upper part of the Gnalta Stage at a locality alongside the old White CliffsMootwingee Road, about eight miles from Mootwingee Homestead. In an unpublished report on this material, R. O. Brunnschweiler in 1957 stated that, although it is not possible to obtain a specific age to the Mootwingee Series on the evidence of the Lingulacea, he considered it reasonable to assume an Upper Devonian or Lower Carboniferous age for the sequence when all the circumstantial evidence was considered. 